\title{
ROLE OF GENETIC FACTORS IN REGULATING CADMIUM UPTAKE, TRANSPORT AND ACCUMULATION MECHANISMS AND QUANTITATIVE TRAIT LOCI MAPPING IN RICE. A REVIEW
}

\author{
RASHEED, A. ${ }^{1}$ - FAHAD, S. ${ }^{2}$ - AAMER, M. ${ }^{3}-$ HASSAN, M. U. ${ }^{3}$ - TAHIR, M. M. ${ }^{4}-$ WU, Z. M. ${ }^{1 *}$ \\ ${ }^{I}$ Key Laboratory of Crop Physiology, Ecology and Genetic Breeding, Ministry of \\ Education/Collage of Agronomy, Jiangxi Agriculture University, Nanchang 330045, PR. China \\ ${ }^{2}$ Department of Agriculture, University of Swabi, Khyber Pakhtunkhwa, Pakistan \\ ${ }^{3}$ Research Center on Ecological Sciences, Jiangxi Agricultural University, Nanchang 330045, \\ PR. China \\ ${ }^{4}$ Department of Soil and Environmental Sciences, Faculty of Agriculture, University of Poonch, \\ Rawalaot, Azad Jammu and Kashmir, Pakistan \\ ${ }^{*}$ Corresponding author \\ e-mail:wuzm@jxau.edu.cn \\ (Received 21 ${ }^{\text {st }}$ Dec 2019; accepted $24^{\text {th }}$ Mar 2020)
}

\begin{abstract}
Rice is an imperative staple food globally; however, it is a major source of cadmium (Cd) intake for humans. Cd is a heavy metal and it has no biological functions in plant and, thus it causes adverse effects in plant and humans. Thus, it is of the utmost importance to minimize the $\mathrm{Cd}$ content in rice to protect humans from its drastic effects. In this review, we discussed the mechanisms related to the uptake and translocation of $\mathrm{Cd}$ in rice. OsNramp5, OsHMA3 OsHMA2 are the genes responsible for Cd uptake, translocation, and sequestration in the vacuole, so modification of these genes function result in no uptake of $\mathrm{Cd}$, and leading to reduction in risk of $\mathrm{Cd}$ toxicity in rice. The different genetic factors involved in $\mathrm{Cd}$ stress and accumulation are shown here and put into several categories according to their function. The identification of novel QTLs ( $q S H 6, q S H 7$ and $q L R 3$ ) detected for morphological traits could be cloned and transferred to develop Cd resistant rice lines. Use of mapping population and some putative quantitative traits loci related to uptake and transport could provide strong base to develop the Cd tolerant genotypes. In addition, use of different agronomic practices may be more fruitful to minimize $\mathrm{Cd}$ in rice.
\end{abstract}

Keywords: $c d$, master assisted selection, QTLs, agronomic practices, toxicity

\section{Background}

$\mathrm{Cd}$ is heavy metal and has no biological role in plants, therefore, it has a high rate of mobility in living things, especially in humans (Song et al., 2015). Heavy metals and mineral oil are the major pollutants causing the soil contamination globally. Globally, it has been reported that about 820 metric tons per year $\mathrm{Cd}$ released into the environment through the weathering of soils, volcanic eruptions (Cook and Morrow, 1995; Hayat et al., 2019). Additionally, human activities also responsible for the addition of more than 8000-10,000 mt Cd per year in our environment (WHO, 1992). The chief sources of Cd entry into our environment includes, chemical fertilizers, sewage sludge and effluents, Cd manufacturing, and run-offs of agriculture (Xue et al., 2014). Cadmium is of great concern, because it enters in the plant leaves in higher quantity and therefore can easy enter in the food chains is ( $\mathrm{Zu}$ et al., 2005). The excess of $\mathrm{Cd}$ cause severe implications in humans, including the dys-functing of kidneys and lungs. Additionally, $\mathrm{Cd}$ also cause 
kidney cancer, breast cancer, failure of heart, hypertensions, proteinuria, eyes cataract, emphysema and renalin sufficiency (Nawrao et al., 2006; Godt et al., 2016). The WHO, has suggested the tolerable weekly intake for the $\mathrm{Cd}$ is $7 \mu \mathrm{g} / \mathrm{kg}$ of body weight. This tolerable weekly intake accounts for $60 \mu \mathrm{g}$ and $70 \mu \mathrm{g}$ for an average $60 \mathrm{~kg}$ and $70 \mathrm{~kg}$ man and woman per day (WHO, 1992). Additionally, the concentration of cd in different food stuff has been given in the Table 1 .

Table 1. Concentration of Cd in different food stuff

\begin{tabular}{c|c}
\hline Food stuff & Cd concentration $(\mu \mathrm{g} / \mathrm{kg})$ \\
\hline Sunflower & 375 \\
Spinach & 117 \\
Potato chips & 93 \\
French fries & 44 \\
Roasted peanuts & 45 \\
Wheat Cereal & 51 \\
Peanut butter & 53 \\
Leaf lettuce & 62 \\
\hline
\end{tabular}

Spungen, 2019

In China about $2.786 \times 109 \mathrm{~m}^{2}$ of agricultural land is contaminated by Cd (Liu et al., 2014). Third major pollutant of supreme hazard to the environment after mercury and lead is $\mathrm{Cd}$ and is considered as the only metal that has health threats to humans and animals at the concentration that is usually not phytotoxic (Ismael et al., 2019). Cd due to its non-essential nature and it causes several deleterious changes in, physiology, biochemistry and morphology of plants even at low concentrations (Song et al., 2015). Reduction in plant growth, development, chlorosis and finally plants death are the most critical symptoms observed under Cd toxicity (Ashraf et al., 2015).

In China, heavy doses of nitrogen resulted in more acidic and $\mathrm{Cd}$ contaminated soils. Cadmium is released from industrial wastes, and sewage irrigation (John et al., 2007; Pandey et al., 2007). Globally, more than 50\% world's population consumes rice as a daily diet (Li et al., 2012b; Song et al., 2015). Therefore, Cd simply moved from soil to rice grains and entered into the human body (Aziz et al., 2015; Xie et al., 2015) and causing several deadly diseases including cancer, heart failure, hypertension and eye cataract formation. Cadmium was responsible for the occurrence of Itai-Itai disease in Japan in 1950s, via consumption of Cd contaminated rice (Horiguchi et al., 1994). Moreover, from 1990-2015, the normal consumption of $\mathrm{Cd}$ in diet in the Chinese population was more than double (Song et al., 2017; Chen et al., 2018). Schematic display of Cd uptake in soil is shown below in Figure 1.

In order to prevent human health from Cd toxicity, reliable steps should be taken to reduce $\mathrm{Cd}$ from rice gains, including agronomic practices, like water management, tillage management and fertilizer management. One of the most powerful techniques to decrease the bioavailable $\mathrm{Cd}$ in rice is in situ immobilization of $\mathrm{Cd}$ (Homa et al., 2016). Absorption, cation exchange and surface complexation are primary mechanisms of $\mathrm{Cd}$ immobilization mediated by agronomic practices (Shaheen and Rinklebe, 2016). Efforts have been made to introduce a novel and cost-effective approaches. In recent studies conducted by Shaheen and Rinklebe (2016) and Li et al. (2017) revealed that lime stone and sugar beet industry meaningfully reduced the cadmium solubility because of higher contents of total calcium carbonate and alkalinity. 


$$
-4007 \text { - }
$$

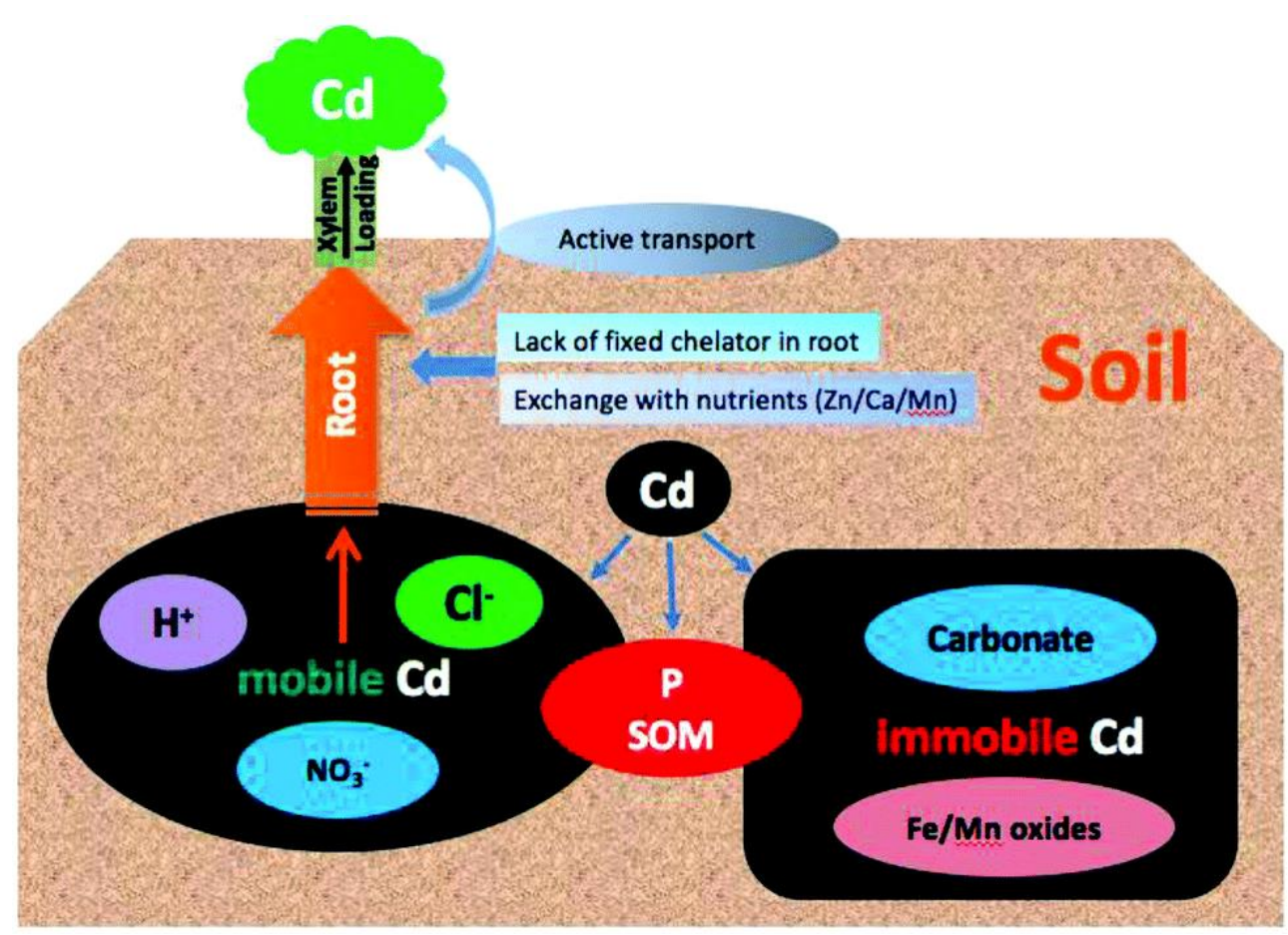

Figure 1. Factors affecting the Cd uptake from the soil (adopted from Huang et al., 2017)

Biochar application decreased the concentration of $\mathrm{Cd}$ as studied by Rinklebe et al. (2016). Use of fertilizers can also alter the soil characteristics like, surface charge, $\mathrm{pH}$, but sometime it directly interacts with soils $\mathrm{Cd}$. Use of fertilizers of phosphate, MPP (potassium phosphate monobasic), TCP (calcium phosphate tribasic), DAP (diammonium phosphate) and SSP (calcium super phosphate on) decreased the bioavailable $\mathrm{Cd}$ in soil as evidenced by Yan et al. (2015) and Li et al. (2017). Thirdly, water management had a key part in reducing the $\mathrm{Cd}$ availability in soil by changing (redox potential) and $\mathrm{pH}$ of soil (Li et al., 2015; Homa et al., 2016). Some of the recent findings of experiments (pot and field) presented that use of flooding before \& after the heading significantly decreased cadmium concentration in rice, while $\mathrm{Cd}$ concentration enhanced under aerobic condition (Hu et al., 2015). Hence, stage of heading in rice stage is a crucial time for lowering Cd entrance. Use of water managing technique would be a cheapest \& cost-effective plan to reduce $\mathrm{Cd}$ assimilation in rice. Crops rotations, intercropping and tillage managing changed the soil, physical, chemical, and biological properties and therefore can reduce Cd uptake in rice as reported by Liu et al. (2016), Li et al. (2017) and Chen et al. (2019). High concentration of organic matter in reduced tillage soil, produced due to deposit of previously grown crops, could increase the adsorption \& complexation of $\mathrm{Cd}$. Guo et al. (2010) reported a decrease in $\mathrm{Cd}$ in rice by application of reduced tillage management practice because of the decrease of microbial activity. Bioremediation is environmental friendly and cost-effective technique to eliminate the heavy metals from a contaminated environment, which involve the use of certain microorganisms to treat the contaminated soils to retain to its healthy state (Gaur et al., 2014). Phyto-extraction is most cost effective and novel technique for elimination of heavy metals and metalloids from polluted oils and water. Cd tolerant plant species that can absorb high concentration of Cd can be used for this strategy (He et al., 2015). Some of the indica rice cultivars have the capability to accumulate the $\mathrm{Cd}$ up to the 
concentration of $3.9 \mathrm{mg} \mathrm{kg}^{-1}$ in grains by using phyto extraction technique. Indica rice variety, Chokoukoku tested for two years and showed a reduction of $883 \mathrm{~g} \mathrm{Cd} \mathrm{ha}^{-1}$, and reduced $\mathrm{Cd}$ in japonica rice grown later with reduced yield (Murakami et al., 2009). It is therefore more viable strategy to use rice cultivars with high contents of cadmium for remediation of contaminated paddy fields. Soil microorganism have strong interaction with plants and can influence plant growth and nutrients mobility, therefore understanding the complex interaction between soil microorganisms and plant is necessary for best results of phyto-remediation (Muehe et al., 2015; Li e al., 2017). Liu et al. (2015) showed that use of plant growth promoting rhizobacteria (PGPR) can improve plant tolerance to heavy metals. They used roots of cadmium accumulating plants, and isolated 9 strains of cadmium tolerant plant growth promoting rhizobacteria and discovered that cadmium hyper-accumulator (S. plumbizincicola) treated with Rhodococcus erythropolis NSX2 and Cedecea davisae LCR1 showed better growth and more cadmium accumulation in shoots. Together all of these agronomic practices are highly recommended to reduce $\mathrm{Cd}$ in rice for decreasing human health risk and to sustain rice production on $\mathrm{Cd}$ effected soils.

QTLs mapping is one of the most powerful technique to locate the gene of interest on chromosomes. Use of different mapping population is an economically sustainable approach to enhance rice production under cadmium stress conditions (Xue et al., 2009). To screen cadmium tolerant genotypes at seedling stage by using different levels of $\mathrm{Cd}$ stress in hydroponic condition is more viable way. Cd toxicity tolerance in rice at morphological, physiological and biochemical has been widely investigated. Use of agronomic practices is an important strategy to minimize $\mathrm{Cd}$ in rice ( $\mathrm{Li}$ et al., 2017). Genetic factors regulating cadmium uptake and transport should need to understand to minimize cadmium contents in grains (Chen et al., 2019). The present review focused on understanding the genetic basis of $\mathrm{Cd}$ stress, uptake, accumulation and transportation in rice and to suggest the ways to improve rice tolerance against the $\mathrm{Cd}$ toxicity. There are several QTLs reported being responsible for Cd accumulation and for breeding Cd free rice cultivars. We need to transfer these QTLs via markers-assisted selection (MAS selection) along with the alleles with novel functions to accumulate low $\mathrm{Cd}$ in rice. The development of Cd resistant rice lines and identification of unknown transporters would be more useful to grow rice on $\mathrm{Cd}$ affected soils to maintain production to ensure the food security.

\section{Survey methodology}

The papers reviewed in this review paper were obtained from the diverse databases and the professional websites. We conducted a survey in the Google scholar, web of science, science direct, PubMed, CAB abstracts, Springer, Taylor and Francis using different keywords including rice, cadmium, genes, QTLs, Cd transport, Cd accumulation, mass selection, Cd stress, Putative QTLs, efflux protein and molecular mechanism to obtain any relevant information regarding, toxic effects of $\mathrm{Cd}$, and genetic factors in regulating the cadmium uptake, transport and accumulation mechanisms in rice.

\section{Rice growth under Cd stress}

Cd toxicity is worldwide problem for crop growth and environmental safety (Aamer et al., 2018). Rice germination and growth is badly affected by Cd stress (He et al., 2006; Liu et al., 2014, 2019a), and exposure of rice seeds to Cd for a long time resulted in lower 
germination (Ahsan et al., 2007), and it also leads to chlorosis and necrosis in rice (Ishimaru et al., 2006). Moreover, Cd stress also caused different physiological as well as physical changes in rice including the reduction in seedling length, number of roots and shoots (Kanu et al., 2017). Cadmium stress affects the stomatal conductance in rice (Li et al., 2012b), absorption and transport of important nutrients in rice crop (Li et al., 2012a, $2012 \mathrm{~b}$ ), and thereby results in severe reduction in final production and grain nutrient contents (Mahmood et al., 2006; Abin and Prasad, 2014; Kanu et al., 2017). Rice cope with Cd toxicity by possessing numerous strategies at molecular and physiological levels (Zhang et al., 2018; Islam et al., 2019).

Plants have mechanisms including the accumulation of $\mathrm{Cd}$ in cell wall and vacuole of root cell, which enable them to stop the transportation of $\mathrm{Cd}$ from root to shoots and thus leads to reduction in the corresponding effects of $\mathrm{Cd}$ on other cells (Fu et al., 2011; Qiu et al., 2011). Many ATP binding-cassette (ABC) protein facilitates the vacuolar spreading of Cd-glutathione in Arabidopsis thaliana (Kim et al., 2007). Rice genes (OsPDR5/ABCG43) are responsible to hold ABC-type proteins, which favors the $\mathrm{Cd}$ extrusion from the cell cytoplasm (Oda et al., 2011). Cadmium transporter (OsHMA3) in membranes of the vacuole in rice roots can enhance rice tolerance to $\mathrm{Cd}$ and lessen the accumulation of $\mathrm{Cd}$ in rice grains (Ueno et al., 2010a; Ke et al., 2015). The vacuoles inside the plants are targeted by detoxification of metal due to chelated toxic metals (Hall, 2002; Haydon and Cobbett, 2007). Organic acids including malate and citrate are accountable for uptake and long-distance transportation of metals into plant vacuoles (Verbruggen et al., 2009; Revathi and Venugopal, 2013). Chelators played a key role in forming a barrier against $\mathrm{Cd}$ accumulation (Nocito et al., 2011). Plants boost the antioxidant defense system to improve tolerance against Cd stress (Hassan et al., 2005; Zhao et al., 2013). The concentration of various substances including, glutathione, salicylic acid, jasmonic acids and nitric oxide considerably increased on exposure to $\mathrm{Cd}$ stress (Wang et al., 2011; Asgher et al., 2015). Mitogen-activated protein kinase OsWJUMK1, OsMSRMK2 regulates auxin signal fluctuations which result in disruption of rice root growth exposed to Cd stress (Agrawal et al., 2003; Zhao et al., 2013). Cadmium stress response and root development are associated with auxin transporter OsAUX1 in rice (Yu et al., 2015). Cadmium accumulation and uptake are reduced by the application of iron, zinc and silicon (Hermans et al., 2013; Chen et al., 2018). Cadmium pathway from roots towards shoots shown in Figure 2.

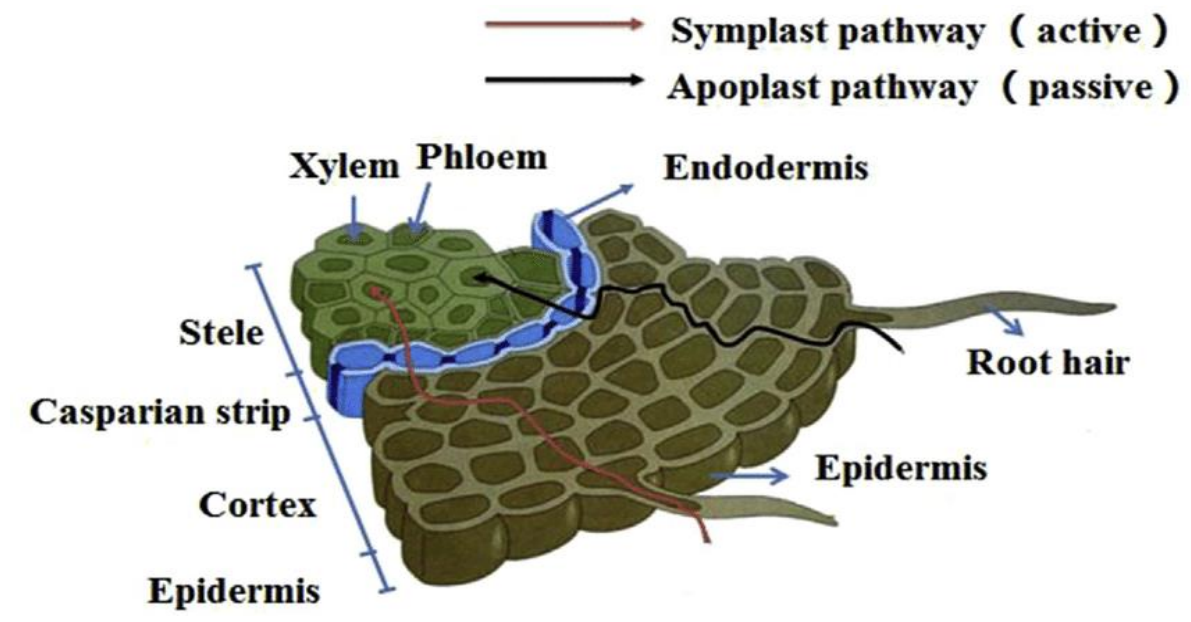

Figure 2. Cd pathway from roots towards shoots (adopted from Li et al., 2017) 
Some important Cd tolerance genes are shown below (Table 2, Figure 3). OsHMA9 is an important copper $(\mathrm{Cu})$ efflux protein, present in the plant plasma membranes; this protein favors the efflux of $\mathrm{Cd}$ from the plant roots, therefore, leads to a substantial reduction in the $\mathrm{Cd}$ accumulation in rice grains (Lee et al., 2007). Knockout of a low $\mathrm{Cd}$ gene (LCD) decreased Cd accumulation and therefore improves the rice growth in $\mathrm{Cd}$ stressed conditions, and low $\mathrm{Cd}$ gene is a protein linked with $\mathrm{Cd}$ equilibrium (Shimo et al., 2011). Arabidopsis thaliana plant growth under Cd stress enhanced by $O s C D T 1$ owing to fact; cysteine rice rich peptide encoded by $O s C D T 1$ improved the rice tolerance against the Cd stress (Kuramata et al., 2008). OsCLT1 probably responsible for normalizing the transfer of glutamylcysteine and glutaione plastids to cytoplasm, which therefore, effects Cd reclamation in rice (Islam et al., 2019). A schematic display of cadmium transport from soil towards rice grains is shown in Figure 4.

Table 2. Putative genes expressed in rice in response to $C d$ stress

\begin{tabular}{|c|c|c|c|c|c|c|c|}
\hline Gene & Chr & Location & Genotype & Screening & Gene name & Role & References \\
\hline OsIRT2 & 3 & $\begin{array}{c}26276301- \\
26277206\end{array}$ & Rice & Hydroponic & $\begin{array}{l}\text { Iron-regulated } \\
\text { transporter }\end{array}$ & $\mathrm{Cd}$ and $\mathrm{Fe}$ transporter & $\begin{array}{l}\text { (Nakanishi et } \\
\text { al., 2006) }\end{array}$ \\
\hline OsIRT1 & 3 & $\begin{array}{c}26286156- \\
26292023\end{array}$ & Rice & Hydroponic & $\begin{array}{l}\text { Iron-regulated } \\
\text { transporter }\end{array}$ & $\mathrm{Cd}$ and $\mathrm{Fe}$ transporter & $\begin{array}{c}\text { (Lee and An, } \\
\text { 2009) }\end{array}$ \\
\hline OsNramp5 & 7 & $\begin{array}{l}8871436- \\
8878905\end{array}$ & Rice & Hydroponic & $\begin{array}{c}\text { Natural Resistance } \\
\text { associated } \\
\text { Macrophage protein }\end{array}$ & $\begin{array}{l}\mathrm{Cd}, \mathrm{Mn} \text { and } \mathrm{Fe} \\
\text { Transporters }\end{array}$ & $\begin{array}{l}\text { (Ishimaru et } \\
\text { al., 2012) }\end{array}$ \\
\hline OsNrampl & 7 & $\begin{array}{l}8966025- \\
8970882\end{array}$ & Rice & Hydroponic & $\begin{array}{c}\text { Natural resistance- } \\
\text { associated } \\
\text { macrophage protein }\end{array}$ & $\begin{array}{l}\mathrm{Cd} \text { and } \mathrm{Fe} \\
\text { transporters }\end{array}$ & $\begin{array}{l}(\text { Takahashi et } \\
\text { al., 2011) }\end{array}$ \\
\hline OsZIP1 & 1 & $\begin{array}{c}42905566- \\
42907474\end{array}$ & Rice & Hydroponic & $\begin{array}{c}\text { Zinc- and iron- } \\
\text { regulated transporter }\end{array}$ & $\begin{array}{l}\mathrm{Cd} \text { and } \mathrm{Zn} \\
\text { transporter }\end{array}$ & $\begin{array}{l}\text { (Ramesh et } \\
\text { al., 2003) }\end{array}$ \\
\hline OsHMA3 & 7 & $\begin{array}{l}7405745- \\
7409553\end{array}$ & Rice & & $\begin{array}{c}\text { P-Type Heavy Metal } \\
\text { ATPase }\end{array}$ & $\begin{array}{c}\text { Sequestrate } \mathrm{Cd} \text { in the } \\
\text { plant roots }\end{array}$ & $\begin{array}{c}\text { (Ueno et al., } \\
2010 \mathrm{~b})\end{array}$ \\
\hline OsHMA2 & 6 & $\begin{array}{c}29477949- \\
29480905\end{array}$ & Rice & Hydroponic & $\begin{array}{c}\text { P-Type Heavy Metal } \\
\text { ATPase }\end{array}$ & $\begin{array}{c}\mathrm{Cd} \text { and } \mathrm{Zn} \\
\text { translocations }\end{array}$ & $\begin{array}{l}\text { (Takahashi et } \\
\text { al., 2012) }\end{array}$ \\
\hline OsZIP7 & 5 & $\begin{array}{c}6090801- \\
6094068\end{array}$ & Rice & $\begin{array}{l}\text { HS/field } \\
\text { screening }\end{array}$ & $\begin{array}{c}\text { Zinc- and iron- } \\
\text { regulated transporter }\end{array}$ & $\begin{array}{c}\mathrm{Cd} \text { and } \mathrm{Zn} \\
\text { accumulation }\end{array}$ & $\begin{array}{l}\text { (Tan et al., } \\
\text { 2019) }\end{array}$ \\
\hline OsLCT1 & 6 & $\begin{array}{c}22566775- \\
22571982\end{array}$ & Rice & & $\begin{array}{c}\text { Low affinity cation } \\
\text { transporter }\end{array}$ & $\begin{array}{l}\mathrm{Cd} \text { transporter in } \\
\text { phloem }\end{array}$ & $\begin{array}{l}\text { (Uraguchi et } \\
\text { al., 2011) }\end{array}$ \\
\hline OsMTP1 & 5 & $\begin{array}{c}1675488- \\
1679056\end{array}$ & Rice & & $\begin{array}{l}\text { Metal tolerance } \\
\text { protein gen }\end{array}$ & Cd translocation & $\begin{array}{c}\text { (Yuan et al., } \\
\text { 2012) }\end{array}$ \\
\hline OsZIP6 & 5 & $\begin{array}{r}3807974- \\
3810752\end{array}$ & Rice & Hydroponic & $\begin{array}{c}\text { Zinc- and iron- } \\
\text { regulated transporter }\end{array}$ & Cd transport & $\begin{array}{l}\text { (Kavitha et } \\
\text { al., 2015) }\end{array}$ \\
\hline PEZ1 & 3 & $\begin{array}{c}20793053- \\
20799805\end{array}$ & Rice & & $\begin{array}{l}\text { Phenol efflux } \\
\text { protein }\end{array}$ & Cd accumulation & $\begin{array}{l}\text { (Ishimaru et } \\
\text { al., 2011) }\end{array}$ \\
\hline OsCDT4 & 2 & $\begin{array}{c}6078179 \\
6079111\end{array}$ & Rice & Hydroponic & $\begin{array}{c}\text { Encoding a Cys-rich } \\
\text { peptide }\end{array}$ & Cd uptake inhibitor & $\begin{array}{l}\text { (Kuramata et } \\
\text { al., 2008) }\end{array}$ \\
\hline OsMSRMK3 & 6 & $\begin{array}{c}29398191- \\
29402466\end{array}$ & Rice & Invitro/vivo & $\begin{array}{l}\text { Mitogen-activated } \\
\text { protein kinase }\end{array}$ & Cd signal & $\begin{array}{l}\text { (Agrawal et } \\
\text { al., 2003) }\end{array}$ \\
\hline OsABCG43 & 7 & $\begin{array}{c}20214025- \\
20218702\end{array}$ & Rice & & $\begin{array}{c}\text { ATP-binding } \\
\text { cassette transporter }\end{array}$ & compartmentalization & $\begin{array}{l}\text { (Oda et al., } \\
\text { 2011) }\end{array}$ \\
\hline OsCLT1 & 1 & $\begin{array}{c}42086484- \\
42095424\end{array}$ & Rice & Hydroponic & $\begin{array}{c}\text { CRT-like transporter } \\
1\end{array}$ & Cd tolerance & $\begin{array}{c}\text { (Yang et al., } \\
\text { 2016b) }\end{array}$ \\
\hline
\end{tabular}




$$
-4011 \text { - }
$$

Chr. 1 Chr. 2 Chr. 3 Chr. 4 Chr. 5 Chr. 6 Chr. 7 Chr. 8 Chr. 9 Chr. 10 Chr. 11 Chr. 12
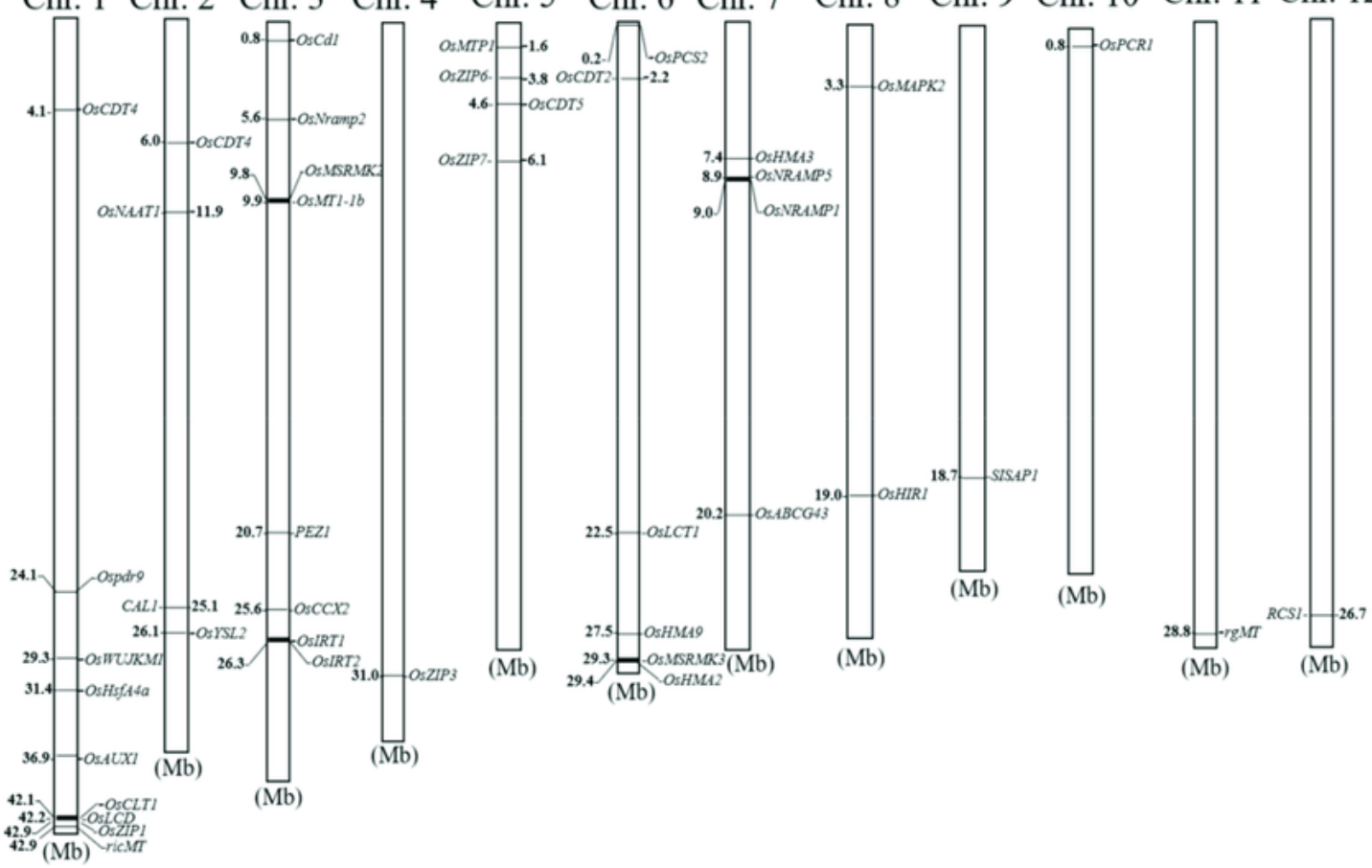

Figure 3. Physical location of genes related to Cd toxicity tolerance in rice (adopted from Chen et al., 2019)

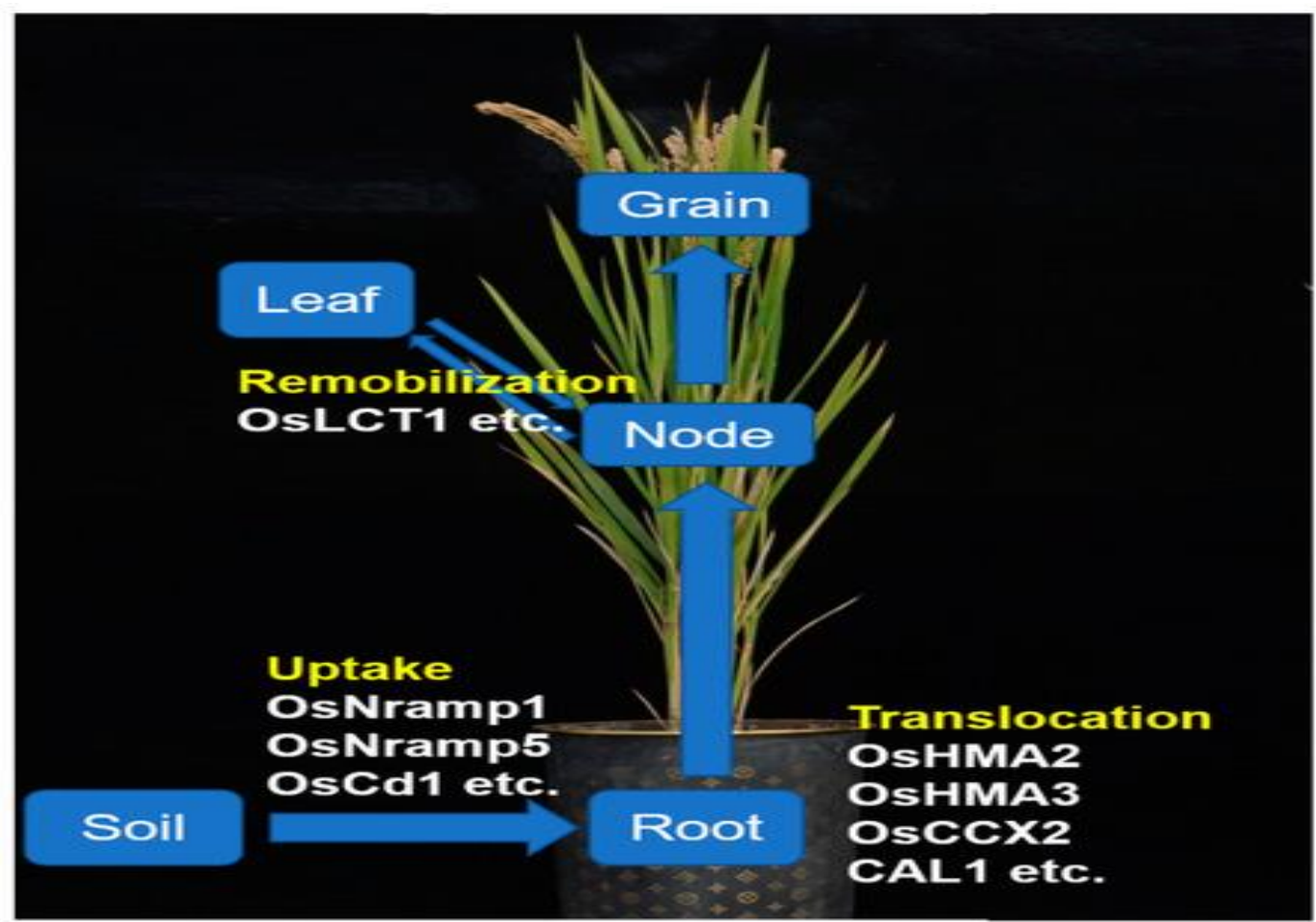

Figure 4. Shows how Cd moves from soil to roots. First cadmium moves from soil to root and grains and this process is mediated by the genes (OsNramp1, OsNramp5, and OsCd1) (adopted from Chen et al., 2019) 


\section{Cd uptake and transport mechanism in rice}

Cd uptake and transport pathway in rice plant include these four steps: (i) uptake via roots; (ii) transportation to shoots via xylem tissues (iii) circulation and transport by the plant nodes (iv) Cd passage to grains from leaf blades by the phloem as shown in Figure 4 (Chen et al., 2019). The Figure 4 shows, how Cd moves from soil to roots. First cadmium moves from soil to root and grains and this process is mediated by the genes (OsNramp1, OsNramp5, and OsCd1) as shown in Figure 4 (Chen et al., 2019).

\section{Cd tolerance genes in rice}

Mechanisms of uptake of some important elements ( $\mathrm{Mn}, \mathrm{Zn}$, and $\mathrm{Fe}$ ) which are responsible for $\mathrm{Cd}$ entrance into rice plants is described by (Abin and Prasad, 2014; Islam et al., 2019). Cadmium efflux activity in yeast is shown by iron transporters (OsIRT1 and OsIRT2) which shows that OSIRT1 and OSIRT2 may have a role in the uptake of Cd in the root system (Nakanishi et al., 2006; Abin and Prasad, 2014). Expression of OSIRT1 considerably improved the $\mathrm{Cd}$ in roots and shoots in MS medium presented by Murashige and Skoog with surplus $\mathrm{Cd}$ but no noticeable phenotype was detected under field conditions, proposing that OSIRT1 may be responsible for $\mathrm{Cd}$ uptake in rice but environment had enormous effects on its contribution (Lee et al., 2007; Lee and An, 2009). Cadmium uptake in rice roots owing to natural resistance associated with macrophage protein 5 OsNramp5 which is accountable for the transport of $\mathrm{Cd}$ from soil solution to root cells (Ishimaru et al., 2012; Sasaki et al., 2012). A researcher recently identified the main quantitative traits loci ( $q$ GMN7.1) for Cd tolerance (Liu et al., 2017). New most effective lines of rice with less $\mathrm{Cd}$ accumulation have been developed by bumping out the metal transporters (OsNramp5). Using (CRISPR/CAS9) system, a chain of indica rice lines having the capability of accumulating low $\mathrm{Cd}$ were developed. OsNRAMP1 genes located on the plasma membrane participated in $\mathrm{Cd}$ transport activity in roots cells (Takahashi et al., 2011; Islam et al., 2019). Yeast sensitivity to $\mathrm{Cd}$ is increased by the function of OSZIP1; a zinc-regulated/iron-regulated transporter-like protein (Ramesh et al., 2003), and Cd uptake in Xenopus leaves oocytes could be enhanced by OsZIP6 overexpression (Kavitha et al., 2015).

The key factor defining the $\mathrm{Cd}$ accumulation in shoots is xylem-mediated $\mathrm{Cd}$ translocation (Uraguchi and Fujiwara, 2012), and OsHMA2 and OsHMA3 (Yamaji et al., 2013; Kavitha et al., 2015). Transport of Cd from roots to shoots is controlled by OsHMA2 and it has important role in regulating the spread of $\mathrm{Cd}$ via phloem to developing tissues (Takahashi et al., 2012). OsHMA3 has the main part in vacuolar requisition of $\mathrm{Cd}$ in cells of the root, the over-expression of OsHMA3 decreases the Cd burden in the xylem and $\mathrm{Cd}$ accretion in the plant shoot. Moreover, the OSHMA3 deficiency leads to higher Cd concentration both in plant roots and shoots (Ueno et al., 2010a). OsZIP7 has substantial role in the xylem loadings in the roots, and to bring the $\mathrm{Cd}$ and $\mathrm{Zn}$ in the upper parts of rice (Tan et al., 2019). Cadmium transfer from xylem to phloem by the plant nodes has imperative part in the Cd transportation to grains (Fujimaki et al., 2010). OsLCT1 is a Cd efflux carrier located on plasma membrane and accountable for phloem Cd transportation (Uraguchi et al., 2011). OsLCT1 expression was found to be higher in nodes and leaf blades during the propagative period, particularly in node I. The Cd concentration in the rice grains, as well as the exudates of phloem in RNAi plants were appreciably decreased compared with wild plants, however, the Cd concentration in the xylem sap remained same in both plants. The current outcomes indicated that OsLCT1 
genes in the leaf blade of plants help in re-mobilization of $\mathrm{Cd}$ by the phloem. Moreover, in node I, OsLCT1 has an important part in the intra-vascular Cd translocation, which involves in translocation of $\mathrm{Cd}$ from a larger vascular bundle to diffused ones attached with the panicle (Uraguchi et al., 2011). Figure 3 and Table 2 showed positions of cloned cadmium stress-related genes in rice chromosomes.

\section{Molecular mechanism behind Cd accumulation}

The major transporter for Cd in rice roots is OsNramp5 family (Sasaki et al., 2012), which is the transporter of divalent cations like, Fe and Cd (Supek et al., 1996), while one OsNrat1 transfer toxic aluminum in rice (Xia et al., 2010). OsNramp5 is also controlled Mn uptake in rice (Sasaki et al., 2012). The knockout of this gene results in complete loss of $\mathrm{Cd}$ uptake which showed that this gene is responsible for Cd uptake. OsIRT1 and OsIRT1 are also responsible for Cd uptake in rice (Nakanishi et al., 2006). Ample $\mathrm{NO}_{3}$ enriched $\mathrm{Cd}$ efflux in the elongation zone of rice roots by enhancing OSIRTI expression causes more uptake and accumulation of $\mathrm{Cd}$ in rice grains (Yang et al., 2016a). The second important step is vacuolar sequestration of $\mathrm{Cd}$ in rice roots. OsHMA3 a major member of heavy metals family involved in this process. This gene was isolated from large QTLs located on the short arm of chromosome 7 resulting from the cross a cross among indica cultivar (Anjana Dhan) which contains more Cd contents in grain, and second japonica cultivar (Nipponbare) with lower contents of cadmium (Ueno et al., 2009). OsHMA3 is mostly expressed in the roots, and its expression is not affected by $\mathrm{Cd}$ exposure. A recent study showed that the novel function of OsHMA3 named as zinc carrier (Sasaki et al., 2014).

The third step is root to shoot translocation of $\mathrm{Cd}$. OsHMA3 was studied to be accountable for translocation from root to shoot in rice (Yamaji et al., 2013). This gene is localized in the plasma membrane and pericycle of roots. The knockout in the activity of this gene caused a decrease in $\mathrm{Cd}$ accumulation in yeast. The final stage of this mechanism is $\mathrm{Cd}$ accumulation in rice grains. OsHMA2 is responsible for $\mathrm{Cd}$ distribution in rice grains, more importantly, its functions appeared to be stronger at the reproductive stage in node 1; OsHMA2 is present at the phloem of enlarged and diffuse vascular bundles in node 1 (Yamaji et al., 2013). The knockout of OsHMA2 resulted in the reduction in the concentration of $\mathrm{Zn}$ and $\mathrm{Cd}$ in upper nodes and reproductive organs compared with wild-type rice. OsLCT1 (Oryza sativa) low-affinity cation transporter 1 involved in the intravascular transfer of Cd. OsLCTI is localized in the plasma membrane and represents efflux carrying activity for $\mathrm{Cd}$ and $\mathrm{K}$, and not for the $\mathrm{Fe}$ and $\mathrm{Na}$ (Uraguchi et al., 2011). The knockdown of OsLCT1 resulted in a reduction in Cd concentration in phloem and grains (Uraguchi et al., 2011). Expression of OsLCTI in the nodes was only observed at the ripening stage as compared to OsHMA2 which expressed in nodes throughout the reproductive stage.

\section{Putative QTLs in response to Cd stress in rice}

Rice genotypes have significant genetic diversity regarding their ability to $\mathrm{Cd}$ accumulation and tolerance which stated the scope of selection (Liu et al., 2003; He et al., 2006). Genetic factors controlling $\mathrm{Cd}$ assimilation in rice have scanty described. OsHMA3 encodes a $\mathrm{Cd}$ transporter found in the membrane of vacuoles, which favors the Cd segregation in the vacuole (Liu et al., 2019a). The reduction in OsHMA3 functioning frequently enhanced Cd transfer in shoots and grains of rice (Abe et al., 2013; Liu et al., 2019a). OsHMA3 improves Cd tolerance in the rice plant and reduces the $\mathrm{Cd}$ accretion in 
the rice kernels (Ueno et al., 2010a; Sasaki et al., 2014). A gene $O s C d 1$ from major facilitator superfamily was identified by Yan et al. (2019) through genome-wide association analysis (GAWS) which has an association with the variation for $\mathrm{Cd}$ assimilation in rice. Two quantitative traits loci governing the Cd application in brown rice stated by Sato et al. (2011) $q L C d G 11$ contributed to 9.4-12.9\% phenotypic variance and $q L C d G 3$ contributed 8.3-14\% phenotypic alterations. Yan et al. (2013) made a RIL population of $\mathrm{F}_{7}$ to recognize $\mathrm{Cd}$ cadmium assimilation and dispersal. Abe et al. (2013) studied population containing 46 CSSL (chromosome segment substitution lines) and detected 8 quantitative traits loci correlated with $\mathrm{Cd}$ contents in grain by single-label analysis of variance). Additional different genes QTLs expressed in the rice exposed to Cd stress are given in Table 3.

Table 3. Putative QTLs express during the rice exposure to the Cd stress

\begin{tabular}{|c|c|c|c|c|c|c|c|}
\hline Parents & Population & Stage & Traits & QTLs & Marker & Chr & Ref \\
\hline $\begin{array}{c}\text { Nipponbare/Anjana } \\
\text { Dhan }\end{array}$ & $965 \mathrm{~F} 2$ & $\begin{array}{l}\text { Seedling } \\
\text { stage }\end{array}$ & $\begin{array}{l}\text { Cd concentration } \\
\text { in shoot }\end{array}$ & OsHMA3 & SSR & 7 & $\begin{array}{c}\text { (Ueno et al., } \\
2010 \mathrm{~b})\end{array}$ \\
\hline SNU-SG1/Suv & $91 \mathrm{RIL}$ & $\begin{array}{l}\text { Seedling } \\
\text { stage }\end{array}$ & $\begin{array}{l}\text { Cd concentration } \\
\text { in shoot }\end{array}$ & $\operatorname{sccl0}$ & $124 \mathrm{SSR}$ & 10 & $\begin{array}{c}\text { (Yan et al., } \\
\text { 2013) }\end{array}$ \\
\hline $\begin{array}{c}\text { Koshihikari/LAC23 } \\
46 \text { CSSLs }\end{array}$ & 46 CSSLs & $\begin{array}{l}\text { Seedling } \\
\text { stage }\end{array}$ & $\begin{array}{l}\text { Cd concentration } \\
\text { in shoots }\end{array}$ & $g l G C d 3$ & $345 \mathrm{SNP}$ & 3 & $\begin{array}{c}\text { (Abe et al., } \\
\text { 2013) }\end{array}$ \\
\hline $\begin{array}{c}\text { Anjana } \\
\text { Dhan/Nipponbare }\end{array}$ & $177 \mathrm{~F} 2$ & $\begin{array}{l}\text { Seedling } \\
\text { stage }\end{array}$ & $\begin{array}{l}\text { Root-to-shoot } \mathrm{Cd} \\
\text { translocation }\end{array}$ & $q C d T 7$ & SSR & 7 & $\begin{array}{c}\text { (Ueno et al., } \\
2009)\end{array}$ \\
\hline Tainan1/Chunjiang06 & $\begin{array}{c}\text { 119DH,3651 } \\
\text { BC3F3 }\end{array}$ & $\begin{array}{l}\text { Seedling } \\
\text { stage }\end{array}$ & $\begin{array}{l}\text { Cd accumulation } \\
\text { in leaves }\end{array}$ & $C A L 1$ & RFLP & 1 & $\begin{array}{c}\text { (Luo et al., } \\
\text { 2018) }\end{array}$ \\
\hline JX17/ZYQ8 & $\begin{array}{l}127 \\
\text { cult }\end{array}$ & $\begin{array}{l}\text { Maturing } \\
\text { stage }\end{array}$ & $\begin{array}{l}\text { Cd accumulation } \\
\text { in grains }\end{array}$ & OsCd1 & GWAS & 3 & $\begin{array}{c}\text { (Yan et al., } \\
\text { 2019) }\end{array}$ \\
\hline Sasanishiki/Habataki & $85 \mathrm{BIL}$ & $\begin{array}{l}\text { Maturing } \\
\text { stage }\end{array}$ & $\begin{array}{l}\mathrm{Cd} \text { accumulation } \\
\text { in grains }\end{array}$ & $q G C d 7$ & SSR & 2,7 & $\begin{array}{l}\text { (Ishikawa et } \\
\text { al., 2009) }\end{array}$ \\
\hline Fukuhibik & $126 \mathrm{RIL}$ & $\begin{array}{l}\text { Maturing } \\
\text { stage }\end{array}$ & $\begin{array}{l}\text { Cd accumulation } \\
\text { in grains }\end{array}$ & $\begin{array}{l}g L C d G 3, \\
g L C d G 1\end{array}$ & $454 \mathrm{SNP}$ & 3,11 & $\begin{array}{c}\text { (Sato et al., } \\
\text { 2011) }\end{array}$ \\
\hline $\begin{array}{c}\text { SNU-SG1/Suwon490 } \\
\text { 91 RIL }\end{array}$ & $91 \mathrm{RIL}$ & $\begin{array}{l}\text { Maturing } \\
\text { stage }\end{array}$ & $\begin{array}{l}\mathrm{Cd} \text { accumulation } \\
\text { in grains }\end{array}$ & $\operatorname{gcc} 3, \operatorname{sgr} 5$ & $124 \mathrm{SSR}$ & 3,5 & $\begin{array}{c}\text { (Yan et al., } \\
\text { 2013) }\end{array}$ \\
\hline Xiang 743/Katy & 115 RIL, & $\begin{array}{l}\text { Maturing } \\
\text { Stage }\end{array}$ & $\begin{array}{l}\text { Cd accumulation } \\
\text { in grains }\end{array}$ & $\begin{array}{c}q C d-2, q C d- \\
7\end{array}$ & SSR GWA & 2,7 & $\begin{array}{l}\text { (Liu et al., } \\
\text { 2019b) }\end{array}$ \\
\hline JX17/ZYQ8 & $\begin{array}{l}378 \text { rice } \\
\text { cultivars }\end{array}$ & $\begin{array}{l}\text { Maturing } \\
\text { Stage }\end{array}$ & $\begin{array}{l}\mathrm{Cd} \text { accumulation } \\
\text { in grains }\end{array}$ & $q C d 3, q C d 5$ & $\begin{array}{c}\text { GWAS } \\
\text { (Statistical } \\
\text { approach) }\end{array}$ & 3,5 & $\begin{array}{l}\text { (Hosseini et } \\
\text { al., 2012) }\end{array}$ \\
\hline
\end{tabular}

Chr: chromosomes, Ref: references, RIL: recombinant inbred lines, DH: double haploid, BIL: backcross inbred lines population, CSSL: chromosomal segment substitution lines, SSR: single sequence repeat, RFLP: restriction fragment length polymorphism, SNP: single nucleotide polymorphism, GWAS: genome wide association study

\section{Identification of QTLs is response to Cd toxicity in rice at seedling stage}

Use of mapping population in to identify the putative QTLs in rice regarding Cd toxicity tolerance, has been a fruitful way to screen resistant rice genotypes. Significant difference among the rice genotypes in Cd tolerance at seedling stage has been widely studied (Cheng et al., 2006; Yu et al., 2006; Xue et al., 2009; Ding et al., 2018). Recently lots of genetic factors have been identified controlling $\mathrm{Cd}$ tolerance in rice at seedling stage. Evaluation of rice genotypes in hydroponic condition using different levels of $\mathrm{Cd}$ 
stress is an economically sustainable approach to increase rice production (Ding et al., 2018).

Xue et al., (2009) conducted a hydroponic experiment and reported some of the functional QTLs ( $q S H 6, q S H 7, q R L 1, q C D S 7)$ in rice explaining $9.11 \%, 14.36 \%, 8.11 \%$ and $0.12 \%$ of the phenotypic variance. Positive additive effect was shown by the QTLs for shoot height and allele was contributed by donor parent. These results suggested their novel role in increasing cadmium tolerance at seedling stage. A QTL $q C D 7$ was involved in reducing CD concentration in rice. Wang et al. (2018) identified a cadmium tolerance QTL $q G L R 3$ for leaf rolling in rice and concluded that this region had novel contribution in response to cadmium stress $\mathrm{n}$ rice. Additionally, another major QTL $q L R 1$ was responsible for controlling leaf rolling in $\mathrm{DH}$ population of rice at seedling stage. Defection of QTLs for cadmium toxicity tolerance for morphological traits are rarely reported in rice, however use of high-resolution mapping population, and use of different levels of $\mathrm{Cd}$ in hydroponic condition would be an effective method to identify the putative QTLs controlling Cd tolerance at seedling stage. Hence Cd tolerance could be increased using an effecting nutrient solution and secondly genetically divergent parents to construct progeny to be evaluated in cultural solution Table 4.

Table 4. Some of the novel QTLs identified in rice for morphological traits in hydroponic environment

\begin{tabular}{c|c|c|c|c|c|c|c}
\hline Parents & Progeny & Indexes & QTLs & Stage & Markers & Chr & Ref \\
\hline ZYQ8/JY17 & $127 \mathrm{DH}$ & SH & $q S H 6$ & seedling & 160RFLP & 6 & Xue et al., 2009 \\
\hline ZYQ8/JY17 & $127 \mathrm{DH}$ & SH & $q S H 7$ & seedling & 160RFLP & 7 & Xue et al., 2009 \\
\hline ZYQ8/JY17 & $127 \mathrm{DH}$ & RL & $q R L 1$ & seedling & 160RFLP & 1 & Xue et al., 2009 \\
\hline ZYQ8/JY17 & $127 \mathrm{DH}$ & CDS & $q C D S 7$ & seedling & 160RFLP & 7 & Xue et al., 2009 \\
\hline ZYQ8/JY17 & $27 \mathrm{DH}$ & LR & $q G L R 3$ & seedling & 83SSR/160RFLP & 3 & Wang et al., 2018 \\
\hline ZYQ8/JY17 & $27 \mathrm{DH}$ & LR & $q L R 1$ & seedling & 83SSR/160RFLP & 1 & Wang et al., 2018 \\
\hline ZYQ8/JY17 & $27 \mathrm{DH}$ & GLR & $q L R 9$ & seedling & 83SSR/160RFLP & 9 & Wang et al., 2018 \\
\hline
\end{tabular}

DH: double haploid, QTLs: quantitative traits loci, Chr: chromosomes, Ref: references, RFLP: restriction fragment length polymorphism, SSR: single nucleotide polymorphism, SH: shoot height, LR: leaf rolling,

GLR: green leaf ratio, CDS: cadmium concentration

\section{Conclusion and future research direction}

Globally, Cd toxicity is a serious threat to living organisms especially humans (Aziz et al., 2015). The different agronomic practices like tillage, nutrients management, water management, use of fertilizers could be adopted to minimize Cd uptake in rice (Li et al., 2012b; Kanu et al., 2019). Many genetic factors involved in Cd uptake and accumulation have been identified and fruitful progress has been made in this aspect. The factors affecting uptake and accumulation of $\mathrm{Cd}$ needs to be understand to make strategies for reducing $\mathrm{Cd}$ toxicity. The identification of more unknown transporter and molecules is an urgent need to understand the way through which $\mathrm{Cd}$ is accumulated in rice grains. The use of biotechnological tools is important for this and genes (OsNramp5) mutation (OsNramp5) result in a noticeable reduction in the accumulation of $\mathrm{Cd}$ in rice grains (Ishimaru et al., 2012). Many transporters need to be recognized in future studies by using different techniques. Cd efflux transporters in rice roots exodermis and endodermis cells are accountable for xylem unloading and phloem loading of $\mathrm{Cd}$, however, these was not still studied. There is no specific transporter involved in $\mathrm{Cd}$ accumulation but these are the transporters belong to other metals, like Mn (OsNramp5) and Fe (OsHMA2). We 
cannot use these genes for developing new rice varieties but there is a need to screen new alleles with new functions to develop resistant varieties to $\mathrm{Cd}$ toxicity.

A hybrid cultivar of rice was developed which has low contents of $\mathrm{Cd}$ in rice grain (Tang et al., 2017). The accumulation and translocation of $\mathrm{Cd}$ were reduced by overexpression of functional OsHMA3 (Ueno et al., 2009). Three rice mutants were made by (Ishikawa et al., 2012) using carbon ion-beam irradiation and in these mutants, Cd was not recognized when grown on the Cd stress conditions, additionally, and there was no pronounced difference among the wild and mutants. The use of markers assisted selection is one of the best strategies to identify the locus governing $\mathrm{Cd}$ accumulation in rice. Transfer of QTLs from a low Cd cultivar to a cultivar with higher contents of Cd could be a significant approach (Uraguchi and Fujiwara, 2012). Few genetic factors regarding $\mathrm{Cd}$ accumulation have been recognized and cloned (Ueno et al., 2010a) but natural variation in alleles of $\mathrm{Cd}$ grain accumulation among the varieties has not fully understood.

The present review suggested to do more investigation on the identification of QTLs controlling $\mathrm{Cd}$ accumulation in grain essential to clone further QTLs governing grain $\mathrm{Cd}$ accumulation and use of the theoretical base for MAS (markers assisted selection) to develop rice varieties with low $\mathrm{Cd}$ contents. Secondly, identification of unknown transporters is a fruitful approach to find the novel function and built a barricade against $\mathrm{Cd}$ uptake and accumulation in rice grains. Some of the novel QTLs ( $q S H 6, q S H 7$ and $q L R 3)$ reported for morphological traits should be transferred to develop Cd resistant lines in rice. Hence use of mapping population and screening of genotypes at seedling stage in hydroponic environment would be a powerful way to reduce Cd toxicity in rice. There are a lot of QTLs reported being responsible for Cd accumulation and for breeding $\mathrm{Cd}$ free rice cultivars we need to transfer these QTLs via MAS selection. For instance, Identification of quantitative traits loci from a low cadmium accumulating cultivar and then transfer this QTL to high Cd cultivar may be a more feasible way to decrease Cd accumulation in rice. Additionally, specific farms practices should be adopted to prevent the entry of $\mathrm{Cd}$ in soils. Futuristic studies should be aimed to understand the Cd uptake and translocation in diverse soils and its interference with $\mathrm{Fe}$ and $\mathrm{Zn}$ pathways. Moreover, develop the scrutiny system $\mathrm{Cd}$ in crops and reduce the allowable $\mathrm{Cd}$ in the fertilizers. Moreover, understand the bio-available fractions of $\mathrm{Cd}$ from the different food stuffs and factors influencing the $\mathrm{Cd}$ absorption in human body.

Acknowledgements. The authors would like to thanks the supervisor, Professor Wu Ziming for his valuable suggestions in the preparation of this draft. The authors would like to thank Dr. Saif Ali for English editing and anonymous reviewers; they helped to improve the quality of the paper.

Funding. The research was supported by the National Natural Science Foundation of China (31560350 and 31760350), the National Key Research and Development Program of China (2018YFD0301102), the Key Research and Development Program of Jiangxi Province (20171ACF60018 and 20192ACB60003) and the Jiangxi Agriculture Research System (JXARS-18).

Competing Interests. All authors declare that there are no competing interests. 


\section{REFERENCES}

[1] Aamer, M., Muhammad, U. H., Abid, A., Su, Q., Liu, Y., Adnan, R., Muhammad, A. U. K., Tahir, A. K., Huang, G. (2018): Foliar application of glycinebetaine (GB) alleviates the cadmium $(\mathrm{Cd})$ toxicity in spinach through reducing $\mathrm{Cd}$ uptake and improving the activity of antioxidant systems. - Applied Ecology and Envronment Research 16(6): 7575-7583.

[2] Abe, T., Nonoue, Y., Ono, N., Omoteno, M., Kuramata, M., Fukuoka, S., Yamamoto, T., Yano, M., Ishikawa, S. (2013): Detection of QTLs to reduce cadmium content in rice grains using LAC23/Koshihikari chromosome segment substitution lines. - Breeding Sci 63: 284291.

[3] Abin, S., Prasad, M. (2014): Cadmium minimization in rice. A review. - Agronomy for Sustainable Development 34(1): 155-173.

[4] Agrawal, G. K., Agrawal, S. K., Shibato, J., Iwahashi, H., Rakwal, R. (2003): Novel rice MAP kinases OsMSRMK3 and OsWJUMK1 involved in encountering diverse environmental stresses and developmental regulation. - Biochemical and Biophysical Research Communications 300: 775-783.

[5] Ahsan, N., Lee, S.-H., Lee, D.-G., Lee, H., Lee, S. W., Bahk, J. D., Lee, B.-H. (2007): Physiological and protein profiles alternation of germinating rice seedlings exposed to acute cadmium toxicity. - Comptes Rendus Biologies 330: 735-746.

[6] Asgher, M., Khan, M. I. R., Anjum, N. A., Khan, N. A. (2015): Minimising toxicity of cadmium in plants - role of plant growth regulators. - Protoplasma 252: 399-413.

[7] Ashraf, U., Kanu, A. S., Mo, Z., Hussain, S., Anjum, S. A., Khan, I., Abbas, R. N., Tang, $X$. (2015): Lead toxicity in rice: effects, mechanisms, and mitigation strategies - a mini review. - Environmental Science and Pollution Research 22(23): 18318-18332.

[8] Aziz, R., Rafiq, M. T., Li, T., Liu, D., He, Z., Stoffella, P., Sun, K., Xiaoe, Y. (2015): Uptake of cadmium by rice grown on contaminated soils and its bioavailability/toxicity in human cell lines (Caco-2/HL-7702). - Journal of Agricultural and Food Chemistry 63(13): 3599-3608.

[9] Chen, H., Yang, X., Wang, P., Wang, Z., Li, M., Zhao, F.-J. (2018): Dietary cadmium intake from rice and vegetables and potential health risk: a case study in Xiangtan, southern China. - Science of the Total Environment 639: 271-277.

[10] Chen, J., Zou, W., Meng, L., Fan, X., Xu, G., Ye, G. (2019): Advances in the uptake and transport mechanisms and QTLs mapping of cadmium in rice. - International Journal of Molecular Sciences 20: 1-17.

[11] Cheng, W. D., Zhang, G. P., Yao, H. G., Wu, W., Xu, M. (2006): Genotypic and environmental variation in cadmium, chromium, arsenic, nickel and lead concentrations in rice grains. - Journal of the Zhejiang University Science 7: 565-571.

[12] Cook, M. E., Morrow, H. (1995): Anthropogenic sources of cadmium in Canada. - In: National Workshop on Cadmium Transport into Plants; Canadian Network of Toxicology Centres: Ottawa, ON, Canada.

[13] Fu, X., Dou, C., Chen, Y., Chen, X., Shi, J., Yu, M., Xu, J. (2011): Subcellular distribution and chemical forms of cadmium in Phytolacca americana L. - Journal of Hazardous Materials 186: 103-107.

[14] Fujimaki, S., Suzui, N., Ishioka, N. S., Kawachi, N., Ito, S., Chino, M., Nakamura, S. I. (2010): Tracing cadmium from culture to spikelet: noninvasive imaging and quantitative characterization of absorption, transport, and accumulation of cadmium in an intact rice plant. - Plant Physiology 152: 1796-1806.

[15] Gaur, N., Flora, G., Yadav, M., Tiwari, A. (2014): A review with recent advancements on bioremediation-based abolition of heavy metals. - Environmental Science Processes and Impact 16: 180-193.

[16] Godt, J., Scheidig, F., Grosse-Siestrup, C., Esche, V., Brandenburg, P., Reich, A., Groneberg, D. A. (2016): The toxicity of cadmium and resulting hazards for human health. - Journal of Occupational Medicine and Toxicology 1: 1-22. 
[17] Guo, J., Liu, X. J., Yong, Z., Shen, J. L., Han, W. X., Zhang, W. F., Christie, P., Goulding, K. W. T., Vitousek, P. M., Zhang, F. S. (2010): Significant acidification in major Chinese crop lands. - Science 327: 1008-1010.

[18] Hall, J. (2002): Cellular mechanisms for heavy metal detoxification and tolerance. Journal of Experimental Botany 53: 1-11.

[19] Hassan, M. J., Shao, G., Zhang, G. (2005): Influence of cadmium toxicity on growth and antioxidant enzyme activity in rice cultivars with different grain cadmium accumulation. Journal of Plant Nutrition 28: 1259-1270.

[20] Hayat, M. T., Nauman, M., Nazir, N., Ali, S., Bangash, N. (2019): Environmental hazards of cadmium: Past, present, and future. - In: Hasanuzzaman, M., Prasad, M. N. V., Fujita, M. (eds.) Cadmium Toxicity and Tolerance in Plants. From Physiology to Remediation. Academic Press: London, UK, pp. 163-183.

[21] Haydon, M. J., Cobbett, C. S. (2007): Transporters of ligands for essential metal ions in plants. - New Phytologist 174: 499-506.

[22] He, J., Zhu, C., Ren, Y., Yan, Y., Jiang, D. (2006): Genotypic variation in grain cadmium concentration of lowland rice. - Journal of Plant Nutrition and Soil Science 169: 711-716.

[23] He, S. Y., He, Z. L., Yang, X. E., Stoffella, P. J., Baligar, V. C. (2015): Soil biogeochemistry, plant physiology, and phytoremediation of cadmium-contaminated soils. - Adances in Agronomy 134: 134-225.

[24] Hermans, C., Conn, S. J., Chen, J., Xiao, Q., Verbruggen, N. (2013): An update on magnesium homeostasis mechanisms in plants. - Metallomics 5: 1170-1183.

[25] Honma, T., Ohba, H., Kaneko-Kadokura, A., Makino, T., Nakamura, K., Katou, H. (2016): Optimal soil Eh, $\mathrm{pH}$, and water management for simultaneously minimizing arsenic and cadmium concentrations in rice grains. - Environmental Science and Technolnology 50: 4178-4185.

[26] Horiguchi, H., Teranishi, H., Niiya, K., Aoshima, K., Katoh, T., Sakuragawa, N., Kasuya, M. (1994): Hypoproduction of erythropoietin contributes to anemia in chronic cadmium intoxication: clinical study on Itai-itai disease in Japan. - Archives of Toxicology 68: 632636.

[27] Hosseini, M., Houshmand, S., Mohamadi, S., Tarang, A., Khodambashi, M., Rahimsoroush, H. (2012): Detection of QTLs with main, epistatic and QTL $\times$ environment interaction effects for rice grain appearance quality traits using two populations of backcross inbred lines (BILs). - Field Crops Research 135: 97-106.

[28] Hu, P. J., Ouyang, Y. N., Wu, L. H., Shen, L. B., Luo, Y. M., Christie, P. (2015): Effects of water management on arsenic and cadmium speciation and accumulation in an upland rice cultivar. - Journal of Environmental Science 27: 225-231.

[29] Huang, Y., He, C., Shen, C., Guo, J., Mubeen, S., Yuan, J., Yang, Z. (2017): Toxicity of cadmium and its health risks from leafy vegetable consumption. - Food and Function 8: 129.

[30] Ishikawa, S., Abe, T., Kuramata, M., Yamaguchi, M., Ando, T., Yamamoto, T., Yano, M. (2009): A major quantitative trait locus for increasing cadmium-specific concentration in rice grain is located on the short arm of chromosome 7. - Journal of Experimental Botany 61: 923-934.

[31] Ishikawa, S., Ishimaru, Y., Igura, M., Kuramata, M., Abe, T., Senoura, T., Hase, Y., Arao, T., Nishizawa, N. K., Nakanishi, H. (2012): Ion-beam irradiation, gene identification, and marker-assisted breeding in the development of low-cadmium rice. - Proceedings of the National Academy of Sciences 109: 19166-19171.

[32] Ishimaru, Y., Suzuki, M., Tsukamoto, T., Suzuki, K., Nakazono, M., Kobayashi, T., Wada, Y., Watanabe, S., Matsuhashi, S., Takahashi, M. (2006): Rice plants take up iron as an $\mathrm{Fe}^{3+}$-phytosiderophore and as $\mathrm{Fe}^{2+}$. - The Plant Journal 45: 335-346.

[33] Ishimaru, Y., Kakei, Y., Shimo, H., Bashir, K., Sato, Y., Sato, Y., Uozumi, N., Nakanishi, H., Nishizawa, N. K. (2011): A rice phenolic efflux transporter is essential for solubilizing 
precipitated apoplasmic iron in the plant stele. - Journal of Biological Chemistry 286: 24649-24655.

[34] Ishimaru, Y., Takahashi, R., Bashir, K., Shimo, H., Senoura, T., Sugimoto, K., Ono, K., Yano, M., Ishikawa, S., Arao, T. (2012): Characterizing the role of rice NRAMP5 in manganese, iron and cadmium transport. - 7 Scientific Reports 2: 1-8.

[35] Islam, F., Wang, J., Farooq, M. A., Yang, C., Jan, M., Mwamba, T. M., Hannan, F., Xu, L., Zhou, W. (2019): Rice responses and tolerance to salt stress: Deciphering the physiological and molecular mechanisms of salinity adaptation. - In: Hasanuzzaman, M., Fujita, M., Nahar, K., Biswas, J. K. (eds.) Advances in Rice Research for Abiotic Stress Tolerance, pp. 791-819.

[36] John, R., Ahmad, P., Gadgil, K., Sharma, S. (2007): Antioxidative response of Lemna polyrrhiza L. to cadmium stress. - Journal of Environmental Biology 28: 583-589.

[37] Kanu, A. S., Ashraf, U., Bangura, A., Yang, D., Ngaujah, A. S., Tang, X. (2017): Cadmium (Cd) stress in rice; phyto-availability, toxic effects, and mitigation measures-a aritical review. - IOSR Journal of Environmental Science, Toxicology and Food Technology 11: 7-23.

[38] Kanu, A. S., Ashraf, U., Bangura, A., Yang, D. M., Ngaujah, A. S., Tang, X. (2019): Cadmium (Cd) Stess in rice; phyto-availability, toxic effects, and mitigation measures-a critical review. - IOSR Journal of Environmental Science, Toxicology and Food Technology 11: 55-61.

[39] Kavitha, P. G., Kuruvilla, S., Mathew, M. K. (2015): Functional characterization of a transition metal ion transporter, OsZIP6 from rice (Oryza sativa L.). - Plant Physiology and Biochemistry 97: 165-174.

[40] Ke, S., Cheng, X.-Y., Zhang, N., Hu, H.-G., Yan, Q., Hou, L.-L., Sun, X., Chen, Z.-N. (2015): Cadmium contamination of rice from various polluted areas of China and its potential risks to human health. - Environmental Monitoring and Assessment 187: 1-11.

[41] Kim, D. Y., Bovet, L., Maeshima, M., Martinoia, E., Lee, Y. (2007): The ABC transporter AtPDR8 is a cadmium extrusion pump conferring heavy metal resistance. - The Plant Journal 50: 106-117.

[42] Kuramata, M., Shuichi, M., Yoshihiro, T., Etsuko, K., Chihiro, I., Satoru, I., Shohab, Y., Tomonobu, K. (2008): Novel cysteine-rich peptides from Digitaria ciliaris and Oryza sativa enhance tolerance to cadmium by limiting its cellular accumulation. - Plant Cell and Physiology 50: 106-117.

[43] Lee, S., Kim, Y.-Y., Lee, Y., An, G. (2007): Rice P1B-type heavy-metal ATPase, OsHMA9, is a metal efflux protein. - Plant Physiology 145: 831-842.

[44] Lee, S., An, G. (2009): Over-expression of OsIRT1 leads to increased iron and zinc accumulations in rice. - Plant, Cell \& Environment 32: 408-416.

[45] Li, B., Wang, X., Qi, X., Huang, L., Ye, Z. (2012a): Identification of rice cultivars with low brown rice mixed cadmium and lead contents and their interactions with the micronutrients iron, zinc, nickel and manganese. - Journal of Environmental Sciences 24: 1790-1798.

[46] Li, S., Yu, J., Zhu, M., Zhao, F., Luan, S. (2012b): Cadmium impairs ion homeostasis by altering $\mathrm{K}^{+}$and $\mathrm{Ca}^{2+}$ channel activities in rice root hair cells. - Plant, Cell \& Environment 35: 1998-2013.

[47] Li, Z., Wu, L. H., Zhang, H., Luo, Y. M., Christie, P. (2015): Effects of soil drying and wetting-drying cycles on the availability of heavy metals and their relationship to dissolved organic matter. - Journal of Soil Sediment 15: 1510-1519.

[48] Li, H., Luo, N., Li, Y. W., Cai, Q. Y., Li, H. Y., Mo, C. H., Wong, M. H. (2017): Cadmium in rice: transport mechanisms, influencing factors, and minimizing measures. Environmental Pollution 224: 622-630.

[49] Liu, J., Li, K., Xu, J., Liang, J., Lu, X., Yang, J., Zhu, Q. (2003): Interaction of Cd and five mineral nutrients for uptake and accumulation in different rice cultivars and genotypes. Field Crops Research 83: 271-281. 
[50] Liu, L., Sun, H., Chen, J., Zhang, Y., Li, D., Li, C. (2014): Effects of cadmium (Cd) on seedling growth traits and photosynthesis parameters in cotton (Gossypium hirsutum L.). Plant Omics 7(4): 284-290.

[51] Liu, F., Liu, X., Ding, C., Wu, L. (2015): The dynamic simulation of rice growth parameters under cadmium stress with the assimilation of multi-period spectral indices and crop model. - Field Crops Research 183: 225-234

[52] Liu, Y., Liu, K., Li, Y., Yang, W. Q., Wu, F. Z., Zhu, P., Zhang, J., Chen, L. H., Gao, S., Zhang, L. (2016): Cadmium contamination of soil and crops is affected by intercropping and rotation systems in the lower reaches of the Minjiang River in south-western China. Environental Geochemistry and Health 38: 811-820.

[53] Liu, C., Chen, G., Li, Y., Peng, Y., Zhang, A., Hong, K., Jiang, H., Ruan, B., Zhang, B., Yang, S., Gao, Z., Qian, Q. (2017): Characterization of a major QTL for manganese accumulation in rice grain. - Scientific Reports 7: 17704.

[54] Liu, W., Pan, X., Li, Y., Duan, Y., Min, J., Liu, S., Liu, L., Sheng, X., Li, X. (2019a): Identification of QTLs and Validation of qCd-2 Associated with Grain Cadmium Concentrations in Rice. - Rice Science 26: 42-49.

[55] Liu, X., Chen, S., Chen, M., Zheng, G., Peng, Y., Shi, X., Qin, P., Xu, X., Teng, S. (2019b): Association study seveals genetic loci responsible for arsenic, cadmium and lead accumulation in rice grain in contaminated farmlands. - Frontiers in Plant Science 10: 61.

[56] Luo, J.-S., Huang, J., Zeng, D.-L., Peng, J.-S., Zhang, G.-B., Ma, H.-L., Guan, Y., Yi, H.Y., Fu, Y.-L., Han, B. (2018): A defensin-like protein drives cadmium efflux and allocation in rice. - Nature Communications 9: 1-9.

[57] Mahmood, Q., Hassan, M., Zhu, Z., Ahmad, B. (2006): Influence of cadmium toxicity on rice genotypes as affected by zinc, sulfur and nitrogen fertilizers. - Caspian Journal of Environmental Sciences 4: 1-8.

[58] Muehe, E. M., Weigold, P., Adaktylou, I. J., Planer-Friedrich, B., Kraemer, U., Kappler, A., Behrens, S. (2015): Rhizosphere microbial community composition affects cadmium and zinc uptake by the metal-hyperaccumulating plant Arabidopsis halleri. - Applied Environmental Microbiology 81: 2173-2181.

[59] Murakami, M., Nakagawa, F., Ae, N., Ito, M., Arao, T. (2009): Phytoextraction by rice capable of accumulating $\mathrm{Cd}$ at high levels: reduction of $\mathrm{Cd}$ content of rice grain. Environmental Science and Technology 43: 5878-5883.

[60] Nakanishi, H., Ogawa, I., Ishimaru, Y., Mori, S., Nishizawa, N. K. (2006): Iron deficiency enhances cadmium uptake and translocation mediated by the $\mathrm{Fe}^{2+}$ transporters OsIRT1 and OsIRT2 in rice. - Soil Science \& Plant Nutrition 52: 464-469.

[61] Nawrot, T., Plusquin, M., Hogervorst, J., Roels, H. A., Celis, H., Thijs, L., Vangronsveld, J., Van Hecke, E., Staessen, J. A. (2006): Environmental exposure to cadmium and risk of cancer: A prospective populationbased study. - Lancet Oncol 7: 119-126.

[62] Nocito, F. F., Lancilli, C., Dendena, B., Lucchini, G., Sacchi, G. A. (2011): Cadmium retention in rice roots is influenced by cadmium availability, chelation and translocation.Plant, Cell \& Environment 34: 994-1008.

[63] Oda, K., Otani, M., Uraguchi, S., Akihiro, T., Fujiwara, T. (2011): Rice ABCG43 is Cd inducible and confers $\mathrm{Cd}$ tolerance on yeast. - Bioscience, Biotechnology, and Biochemistry 75: 1211-1213.

[64] Pandey, S., Gupta, K., Mukherjee, A. (2007): Impact of cadmium and lead on Catharanthus roseus-A phytoremediation study. - Journal of Environmental Biology 28: 655-662.

[65] Qiu, Q., Wang, Y., Yang, Z., Yuan, J. (2011): Effects of phosphorus supplied in soil on subcellular distribution and chemical forms of cadmium in two Chinese flowering cabbage (Brassica parachinensis L.) cultivars differing in cadmium accumulation. - Food and Chemical Toxicology 49: 2260-2267.

[66] Ramesh, S. A., Shin, R., Eide, D. J., Schachtman, D. P. (2003): Differential metal selectivity and gene expression of two zinc transporters from rice. - Plant Physiology 133: 126-134. 
[67] Revathi, S., Venugopal, S. (2013): Physiological and biochemical mechanisms of heavy metal tolerance. - International Journal of Environmental Sciences 3(5): 1339-1354.

[68] Rinklebe, J., Shaheen, S. M., Frohne, T. (2016): Amendment of biochar reduces the release of toxic elements under dynamic redox conditions in a contaminated floodplain soil. Chemosphere 142: 41-47.

[69] Sasaki, A., Yamaji, N., Yokosho, K., Ma, J. F. (2012): Nramp5 is a major transporter responsible for manganese and cadmium uptake in rice. - The Plant Cell 24: 2155-2167.

[70] Sasaki, A., Yamaji, N., Ma, J. F. (2014): Overexpression of OsHMA3 enhances Cd tolerance and expression of $\mathrm{Zn}$ transporter genes in rice. - Journal of Experimental Botany 65: 6013-6021.

[71] Sato, H., Shirasawa, S., Maeda, H., Nakagomi, K., Kaji, R., Ohta, H., Yamaguchi, M., Nishio, T. (2011): Analysis of QTL for lowering cadmium concentration in rice grains from 'LAC23'. - Breeding Science 61: 196-200.

[72] Shaheen, S. M., Rinklebe, J. (2016): Impact of different soil amendments on the mobilization and phytoavail ability of toxic metals in a contaminated flood plain soil. International Conference on Heavy Metals in the Environment pp 1-2.

[73] Shimo, H., Ishimaru, Y., An, G., Yamakawa, T., Nakanishi, H., Nishizawa, N. K. (2011): Low cadmium (LCD), a novel gene related to cadmium tolerance and accumulation in rice. - Journal of Experimental Botany 62: 5727-5734.

[74] Song, W. E., Chen, S. B., Liu, J. F., Li, C., Song, N. N., Ning, L., Bin, L. (2015): Variation of Cd concentration in various rice cultivars and derivation of cadmium toxicity thresholds for paddy soil by species-sensitivity distribution. - Journal of Integrative Agriculture 14: 1845-1854.

[75] Song, Y., Wang, Y., Mao, W., Sui, H., Yong, L., Yang, D., Jiang, D., Zhang, L., Gong, Y. (2017): Dietary cadmium exposure assessment among the Chinese population. - PLoS One 12(5): e0177978.

[76] Spungen, J. (2019): Children's exposures to lead and cadmium: FDA total diet study 201416. - Food Additives and Contaminants, Part A 36(6): 893-903.

[77] Supek, F., Supekova, L., Nelson, H., Nelson, N. (1996): A yeast manganese transporter related to the macrophage protein involved in conferring resistance to mycobacteria. Proceedings of the National Academy of Sciences 93: 5105-5110.

[78] Takahashi, R., Ishimaru, Y., Senoura, T., Shimo, H., Ishikawa, S., Arao, T., Nakanishi, H., Nishizawa, N. K. (2011): The OsNRAMP1 iron transporter is involved in Cd accumulation in rice. - Journal of Experimental Botany 62: 4843-4850.

[79] Takahashi, R., Ishimaru, Y., Shimo, H., Ogo, Y., Senoura, T., Nishizawa, N. K., Nakanishi, H. (2012): The OsHMA2 transporter is involved in root-to-shoot translocation of $\mathrm{Zn}$ and Cd in rice. - Plant, Cell \& Environment 35: 1948-1957.

[80] Tan, L., Zhu, Y., Fan, T., Peng, C., Wang, J., Sun, L., Chen, C. (2019): OsZIP7 functions in xylem loading in roots and inter-vascular transfer in nodes to deliver $\mathrm{Zn} / \mathrm{Cd}$ to grain in rice. - Biochemical and Biophysical Research Communications 512: 112-118.

[81] Tang, L., Mao, B., Li, Y., Lv, Q., Zhang, L., Chen, C., He, H., Wang, W., Zeng, X., Shao, Y. (2017): Knockout of OsNramp5 using the CRISPR/Cas9 system produces low Cdaccumulating indica rice without compromising yield. - Scientific Reports 7: 1-12.

[82] Ueno, D., Emi, K., Izumi, K., Tsuyu, A., Masahiro, Y., Feng, M. J. (2009): Identification of a novel major quantitative trait locus controlling distribution of Cd between roots and shoots in rice. - Plant and Cell Physiology 50: 2223-2233.

[83] Ueno, D., Koyama, E., Yamaji, N., Ma, J. F. (2010a): Physiological, genetic, and molecular characterization of a high-Cd-accumulating rice cultivar, Jarjan. - Journal of Experimental Botany 62: 2265-2272.

[84] Ueno, D., Yamaji, N., Kono, I., Huang, C. F., Ando, T., Yano, M., Ma, J. F. (2010b): Gene limiting cadmium accumulation in rice. - Proceedings of the National Academy of Sciences 107: 16500-16505. 
[85] Uraguchi, S., Kamiya, T., Sakamoto, T., Kasai, K., Sato, Y., Nagamura, Y., Yoshida, A., Kyozuka, J., Ishikawa, S., Fujiwara, T. (2011): Low-affinity cation transporter (OsLCT1) regulates cadmium transport into rice grains. - Proceedings of the National Academy of Sciences 108: 20959-20964.

[86] Uraguchi, S., Fujiwara, T. (2012): Cadmium transport and tolerance in rice: perspectives for reducing grain cadmium accumulation. - Rice 5(1): 5 .

[87] Verbruggen, N., Hermans, C., Schat, H. (2009): Molecular mechanisms of metal hyperaccumulation in plants. - New Phytologist 181: 759-776.

[88] Wang, B., Zhu, C., Liu, X., Wang, W., Ding, H., Jiang, M., Li, G., Liu, W., Yao, F. (2011): Fine mapping of qHD4-1, a QTL controlling the heading date, to a 20.7-kb DNA fragment in rice (Oryza sativa L.). - Plant Molecular Biology Reporter 29: 702-713.

[89] Wang, J., Fang, Y., Tian, B., Zhang, X., Zeng, D., Guo, L., Hu, J., Xue, D. (2018): New QTLs identified for leaf correlative traits in rice seedlings under cadmium stress. - Plant Growth Regulation 85: 329-335

[90] World Health Organisation (WHO). (1992): Environmental Health Criteria 134 - Cadmium International Programme on Chemical Safety (IPCS) Monograph. - World Health Organization: Geneva, Switzerland.

[91] Xia, J., Naoki, Y., Tomonari, K., Feng, M. J. (2010): Plasma membrane-localized transporter for aluminum in rice. - Proceedings of the National Academy of Sciences 107: 18381-18385.

[92] Xie, P. P., Deng, J. W., Zhang, H. M., Ma, Y. H., Cao, D. J., Ma, R. X., Liu, R. J., Liu, C., Liang, Y. G. (2015): Effects of cadmium on bioaccumulation and biochemical stress response in rice (Oryza sativa L.). - Ecotoxicology and Environmental Safety 122: 392398.

[93] Xue, D., Chen, M., Zhang, G. (2009): Mapping of QTLs associated with cadmium tolerance and accumulation during seedling stage in rice (Oryza sativa L.). - Euphytica 165: 587-596.

[94] Xue, D. W., Jiang, H., Deng, X. X., Zhang, X. Q., Wang, H., Xu, X. B., Hu, J., Zeng, D., Guo, L., Qian, Q. (2014): Comparative proteomic analysis provides new insights into cadmium accumulation in rice grain under cadmium stress. - Journal of Hazardous Material 280: 269-278.

[95] Yamaji, N., Xia, J., Mitani-Ueno, N., Yokosho, K., Ma, J. F. (2013): Preferential delivery of zinc to developing tissues in rice is mediated by P-type heavy metal ATPase OsHMA2. - Plant Physiology 162: 927-939.

[96] Yan, Y. F., Lestari, P., Lee, K. J., Kim, M. Y., Lee, S. H., Lee, B. W. (2013): Identification of quantitative trait loci for cadmium accumulation and distribution in rice (Oryza sativa L). - Genome 56: 227-232.

[97] Yan, Y., Zhou, Y. Q., Liang, C. H. (2015): Evaluation of phosphate fertilizers for the immobilization of Cd in contaminated soils. - PLOS One 10: e0124022.

[98] Yan, H., Xu, W., Xie, J., Gao, Y., Wu, L., Sun, L., Feng, L., Chen, X., Zhang, T., Dai, C. (2019): Variation of a major facilitator superfamily gene contributes to differential cadmium accumulation between rice subspecies. - Nature communications 10: 2562.

[99] Yang, J., Gao, M. X., Hu, H., Ding, X. M., Lin, H. W., Wang, L., Xu, J. M., Mao, C. Z., Zhao, F. J., Wu, Z. C. (2016a): OsCLT1, a CRT-like transporter 1, is required for glutathione homeostasis and arsenic tolerance in rice. - New Phytologist 211: 658-670.

[100] Yang, Y., Xiong, J., Chen, R., Fu, G., Chen, T., Tao, L. (2016b): Excessive nitrate enhances cadmium (Cd) uptake by up-regulating the expression of OsIRT1 in rice (Oryza sativa). Environmental and Experimental Botany 122: 141-149.

[101] Yu, H., Wang, J., Fang, W., Yuan, J., Yang, Z. (2006): Cadmium accumulation in diVerent rice cultivars and screening for pollution-safe cultivars of rice. - Science of the Total Environment 370: 302-309.

[102] Yu, C., Sun, C., Shen, C., Wang, S., Liu, F., Liu, Y., Chen, Y., Li, C., Qian, Q., Aryal, B. (2015): The auxin transporter, Os AUX 1, is involved in primary root and root hair 
elongation and in Cd stress responses in rice (Oryza sativa L.). - The Plant Journal 83: 818830.

[103] Yuan, L., Yang, S., Liu, B., Zhang, M., Wu, K. (2012): Molecular characterization of a rice metal tolerance protein, OsMTP1. - Plant Cell reports 31: 67-79.

[104] Zhang, X., Wu, H., Chen, L., Liu, L., Wan, X. (2018): Maintenance of mesophyll potassium and regulation of plasma membrane $\mathrm{H}+$-ATPase are associated with physiological responses of tea plants to drought and subsequent rehydration. - The Crop Journal 6: 611620.

[105] Zhao, F. Y., Hu, F., Zhang, S. Y., Wang, K., Zhang, C. R., Liu, T. (2013): MAPKs regulate root growth by influencing auxin signaling and cell cycle-related gene expression in cadmium-stressed rice. - Environmental Science and Pollution Research 20: 5449-5460.

[106] Zu, Y., Li, Y., Chen, J., Chen, H. Y., Li, Q., Schratz, C. (2005): Hyper accumulation of Pb, $\mathrm{Zn}$ and $\mathrm{Cd}$ in herbaceous grown on lead-zinc mining area in Yunnan, China. Environmental International 31(5): 755-762. 